DOI https://doi.org/10.36059/978-966-397-116-2/85-107

\title{
HUMAN LIFE AS THE HIGHEST SOCIAL VALUE AND THE SUBJECT OF LEGAL PROTECTION
}

\section{Dorokhina Yu. A.}

\section{INTRODUCTION}

Article 3 of the Constitution of Ukraine proclaims the fact that a person, his/her life and health, honor and dignity, inviolability and safety are recognized in Ukraine as the highest social value. For that reason, the issues of crime qualification against the most valuable human benefits life and health is of great attention because in the criminal legal aspect such infringements are recognized as the most dangerous.

Human life is a special form of human existence (human organism) characterized by integrity and ability to self-organization; it is the most valuable benefit, which in case of human death can not be renewed. Human life is characterized by reactivity, breathing, thinking, sensitivity, vision, communication, nutrition, growth, movement, metabolism, and reproduction etc.

\section{Human Life as the Highest Social Value}

In all periods of development of civilization, the problems of the human life value, which is the core of the culture of all people, nation and society, play an important role. The right to life is the main human right proclaimed and enshrined in the Universal Declaration of Human Rights dated December 10, 1948, as follows: "Everyone has the right to life, liberty and security of person".

John Locke was the first who formulated and philosophically justified the very idea of human rights. The philosopher called the right to life as one of three natural rights. The thinker considered life, freedom and property to be decisive for a person. He called these rights as inalienable as they are a part of human nature, therefore they can not be granted or withdrawn. This thought of J. Locke was brilliantly continued by Alexander Hamilton one of the founders of the United States, who at one time pointed out: "The sacred human rights of mankind are written by the 
light of the sun, by the hand of God on all people and will never be erased or distorted by any power on the Earth".

In a modern social consciousness, the prevailing idea is that the threat to the human freedoms and rights can only come from the state, a potential bearer of a despotic beginning, and never from the people who are immanently striving for freedom. This position seems obvious to many people, but needs to be clarified. Even if, in most totalitarian doctrines, the subjectivity of the state is humiliated: it acts formally not only as one of the most important components of civilization, but also as an instrument of preservation and domination of the true subject of history - the people ${ }^{1}$.

However, an attempt to define human rights as the highest value also carries "a seed of the eternal". At that time another prominent German philosopher F. Nietzsche showed the problematic nature of the philosophy of values, which are known to have their own destiny. C. Schmitt pointed out to the problem of interpreting human rights as eternal values, noting the following: "If we consider the fundamental rights as values, then the question naturally arises: why these values (life, freedom, property) should be considered as such only in relation to the state? It would be logical to spread such attitude to them on legal relations that arise between citizens". As C. Schmitt emphasized in his work under the expressive title "Tyranny of Values", "get dressed in subjectivity, freedom is replaced by the objectivity of values, which is objectivity only by imagination. Someone who refers to values can not oppose anything to the pursuit of revaluation, discredit, or doubt in one or another value"2. Indeed, what prevents the sovereign from reviewing the status of these norms-values, and are there any grave obstacles to this? According to K. Schmitt, such justification of value-based principles is a weak link in this version of human rights, and in this case, even the provision of "transcendental" status to these legal values does not help much. Certainly, C. Schmitt continues that constitutional norms could be considered as expressions of "a system of values" or "a natural-legal system" (since they are fundamental rights). However, the inevitable consequence and reckoning will be loss of value of the very text of the Constitution and its conceptual structure. At the end, we gain the value with a "positive" and

\footnotetext{
${ }^{1}$ Поппер К. Открытое общество и его враги : в 2 т. / К. Поппер. - Москва, 1992. - Т. 2. Время лжепророков: Гегель, Маркс и другие оракулы. - С. 76-77.

${ }^{2}$ Schmitt C. Die Tyrannei der Werte / C. Schmitt. - Hamburg, 1979. - S. 33-37., c. 33
} 
"suprapositive" property, but the experience of recent decades gives a lot of reasons for doubts (moreover, not only in Germany) in their stabilizing role" $"$.

Therefore, it is reasonable to point out that: either fundamental rights (the right to life) are values subject to the same legal protection both in relations between citizens and the state as well as between citizens, or in one case the fundamental rights are non-acquired eternal values, and in the second - subjective acquired rights. According to C. Schmitt, there is such difficult situation which interpreters of the Constitution get as the system of values, where one of the basic (main) values, along with property and freedom, is human life.

At the same time, the reception of the principle of primacy of human rights, carried out in Ukrainian constitutionalism, can be regarded as a peculiar presumption of "guilt of the state" towards a citizen. The state, as noted by the well-known constitutionalist J. Isensee, "squeezes into the Procrustean bed of constitutional duties, while the citizen is given freedom in relation to the state, and through the citizen - the whole society" 4 .

The consolidation of human rights and freedoms as the highest value means that in relations of a person, society and the state the priority belongs to the rights and legitimate interests of a person. In other words, if a person is the highest value, then his/her rights are the values of the same highest order that "precede the Constitution" and even have primacy over state sovereignty ${ }^{5}$. In this regard, the question arises: is there anything in this world that is above human rights; or human rights are always "over the world"?

In our view, in case of such "conceptualization" not any state can simply exist under a more or less serious test. The liberal principle of the superiority of the rights of a person over the rights of the state in its practical implementation inevitably leads to the collapse of the state and, accordingly, to the collapse of the human rights, because without the state they will not be protected by anyone. In support of the above, it is reasonable to quote I. Kant: "Democracy in the proper sense of the word is inevitably despotism, because it establishes such executive power,

\footnotetext{
${ }^{3}$ Schmitt C. Die Tyrannei der Werte / C. Schmitt. - Hamburg, 1979. - S. 33-37., c. 34

${ }^{4}$ Isensee J. Burgerfreiheit und Burgertugend / J. Isensee // Der Preis der Freiheit. - Kцln, 1998. - S. 20., c. 20

5 Садовникова Г. Д. Комментарий к Конституции Российской Федерации (постатейный) Г. Д. Садовникова ; отв. ред. Конюхова И. А. (Умнова). - Москва : Юрайт, 2000. - 189 с., с. 15-16
} 
where everyone decides about one person and in any case against one person ... this is a contradiction of the common will with itself and with freedom ${ }^{6}$. From incompatibility of unlimited democracy with the human freedom and dignity it follows that from standpoint of a liberal worldview, for which the very highest value is the person (his/her rights and freedoms), only the power of laws can be just.

Article 3 of the Constitution of Ukraine stipulates: "Human rights and freedoms and their guarantees determine the content and direction of the state. The state is responsible to a person for its activities. The assertion and guarantee of human rights and freedoms is the main responsibility of the state". It can be said that this article "sets the tone" with all the following constitutional provisions, reflecting the real or desired position of a person in the Ukrainian society, regulating his/her relations with the state, directing the state policy. In a word, it is the basic article that characterizes the very foundations of the social and state system enshrined in the Constitution. It is the normative and legal foundation for the humanistic direction of the development of public and state life in Ukraine.

The above provision briefly reproduces the content of the conceptual foundations of the preamble of the Universal Declaration of Human Rights, which in itself should determine the compliance of the provisions of the Constitution of Ukraine with international human rights standards. Among these grounds, it should be noted, in particular, "belief in basic human rights, in the dignity and value of the human personality", as well as "recognition of the dignity inherent in all members of the human family and their equal and inalienable rights". The above postulates are reproduced in the preamble of the International Covenant on Civil and Political Rights and the International Covenant on Economic, Social and Cultural Rights.

Certainly, the recognition of human life as a social value is fundamentally important: it means that human life is a value not only for person himself/herself, but for society as a whole, for community. Moreover, since this value is the highest, no other phenomenon can be appreciated by a society higher than human life, can not, so to speak, surpass its value.

${ }^{6}$ Кант И. К вечному миру / И. Кант // Кант И. Соч. : в 6 т. - Москва, 1966. - Т. 6. - С. 269-270., с. 269 
Objectively, the right to life serves as a benchmark, a criterion for the whole institute of rights and freedoms in a democratic society. When it is stated that human rights are the highest social value, this also implies to the person as the holder of these rights. Without a person, outside, in isolation from a person, any rights turn into something that means abstraction. Thus, this right, undoubtedly, forms the basis of all other rights and freedoms. It represents the absolute value of world civilization, since all other rights lose meaning and significance in the event of the death of person. Definitely, a person and his/her life are the basic, fundamental value with which all legal systems should relate. The right to life is given by person by nature (in some concepts - by God), but never by state or power. The latter are only obliged to recognize, respect and defend this value in all respects that dominates over all others.

At the present stage, the concept of human rights has become a leading element of political liberalism, its cornerstone, almost metaphysical level. This is the fundamental level of the general liberal theory in which metaphysics is "the discovery of the ultimate cause of things, their first and universal beginning", where one of the first must be the question about "the grounds" and the "first and universal principle" of life $^{7}$.

Human life is not only a subjective right protected by legal norms, but also an independent social, spiritual and biological value. Protection of each person's life is a primary task of criminal law. Many lawyers have dedicated their works to the criminal legal life protection, but their works do not exhaust all the problems of criminal law in relation to the comprehensive life protection. One of these problems is the question when life begins, and, accordingly, its criminal legal protection. Clarification of this issue is directly related to possibility of bringing the guilty persons to criminal liability for infringement on life.

\section{Human Life as the Subject of Legal Protection}

As to the question of the beginning of life in legal and medical literature, there are many different points of view. In particular, researchers determine the beginning of human life from a certain stage of physiological birth. At the same time, one group of scientists believes that

\footnotetext{
${ }^{7}$ Мондін Б. Підручники систематичної філософії : в 6 т. / Б. Мондін ; пер. 3 італ. Б. Завідняка. Жовква : Місіонер, 2010. - Т 3. Онтологія і метафізика. - 284 с., с. 8
} 
human life begins with the moment when a child is capable of independent existence, completely separated from the mother's body and has made his/her first breath (B. Zdravomyslov, O. Krasikov, S. Boyarov, O. Naumov, M. Shargorodsky etc.). However, in 1923 S.V. Pozdnyshev wrote: "The most convincing proof of the newborn's life is breathing. However, there are possible cases when the child was not breathing, but already lived through the blood circulation"

Other scholars note that the moment of the beginning of human life is associated with such a stage of physiological birth delivery, when only a part of the child emerged from the mother's womb (V. S. Borodin, O. O. Zhizhylenko, B. S. Utevsky, A. A. Piontkovsky, Ye. F. Pobegailo, Yu. B. Khimyak at al.). In this regard, at that time V. D. Nabokov noted: "... The moment of birth ... should be considered the beginning of birth delivery, and at the same time not in the understanding of the physiological beginning (for example, the appearance of pain), but in the sense of the appearance of any part of the child's body outside: from this moment the concept of the fetus is replaced by the concept of the child"9.

Some authors point out that the initial boundary of human life should be associated with the emergence of the formed mass of brain cells, which makes the fetus viable ${ }^{10}$. Proponents of this position came to the conclusion that, from a legal point of view, the beginning of human life is the birth (formation) of the brain, namely: the achievement of twenty two weeks of intrauterine development by the fetus ${ }^{11}$. At the same time, it should be noted that in modern criminal legal literature attempts are made to determine the moment of the beginning of life in another way. So, according to Professor V. O. Glushkov, the life of a human fetus after twenty eight weeks - an additional object of illegal abortion, so his/her death as a result of an illegal operation should be qualified as a murder ${ }^{12}$.

As to the beginning of life, it is possible to recognize the position of M. Ya. Korzhansky as substantiated, who notes that this is the beginning of physiological birth delivery, "when the development of the fetus has

\footnotetext{
${ }^{8}$ Позднышев С.В. Очерк основных начал науки уголовного права. Особенная часть М., 1923, С. 6

9 Набоков В.Д. Элементарный учебник особенной части русского уголовного права / В.Д. Набоков. - СПб : $1903 .-136$ с., с. 5

10 Шарапов Р. Начало уголовно-правовой охрани жизни человека / Р. Шарапов // Уголовное право. - 2005. - № 1. - С. 70-81., с. 75

11 Трубников В.М. Концепція кримінально-правової охорони : монографія / В.М. Трубников, Т.А. Павленко. - Х. : Харків юридичний, 2009. - 288 с, с. 117

${ }^{12}$ Глушков В. А. Ответственность за преступления в области здравоохранения / В. А. Глушков. К. : Вища школа, 1987. - 200 с., с. 21
} 
come to an end and it has matured for independent life beyond the mother's body, a new life appears that should already be protected by a criminal law"13.

There is a point of view according to which the moment of the beginning of life is the moment of fertilization ${ }^{14}$. In legal science there are steady trends of support of exactly this point of view. So, some scientists point out that "the period of intrauterine development of a person is an early period of his/her biological life. Being in the maternal womb in the state of the embryo, he/she is bodily independent, because he/she is not a part of the body of the carrier and is capable of self-development: after all, the vital processes taking place in him/her, act as an internal impulse for his/her development. The body of the mother is only an ideal development environment. From the birth begins the second stage of the biological existence of person, more precisely, the stage of his/her stay in the social environment. This proves the incorrectness of the existing opinion that human life begins with his/her birth. It should be corrected: the social life of a person begins from the moment of his/her birth" ${ }^{\text {" }}$.

Some authors believe that "the legal relation to the status of embryos should be based on the recognition of the fact that the embryo is not a part of the mother's body, but the beginning of a new life"16. It should be emphasized that the given position has its normative consolidation. In particular, in civil legislation of Ukraine in Article 1222 of the Civil Code of Ukraine, the right to inheritance arises in a person who was conceived during the life of the testator and born alive after the opening of the inheritance.

\footnotetext{
${ }^{13}$ Коржанський М.Й. Кримінальне право. Законодавство України. Частина Особлива. Курс лекцій / М.Й. Коржанський. - К. : Атіка - 2001. - 544 с., с. 49

14 Попов А.Н. Преступления против личности при смягчающих обстоятельствах / А.Н. Попов. СПб. : Юридический центр Пресс, 2001. - 472 с., с. 56; Порошук С.Д. Право людини на життя як об’єкт нормативно-правового регулювання: сучасний стан, проблеми в Україні / С.Д. Порощук, О.В. Онуфрієнко // Вісник Луганського інституту внутрішніх справ МВС України: Наук.-теор. журнал. - Луганськ : Ін-т внутрішніх справ МВС України, 1998. -Вип. 2. - С. 3-18; Голиченков В.А. Заявление кафедры эмбриологии биологического факультета МГУ 03.09.1993 [Электронный ресурс] / В.А. Голиченков, Д.В. Попов. - Режим доступа : http://www.patriarchia.ru/db/text/3122712.html.

15 Селихова О. Г. Конституционно-правовые проблемы осуществления права индивидов на свободу и личную неприкосновенность : автореферат дис. на соискание науч. степени канд. юрид. наук : спец. 12.00 .02 «Конституционное право; муниципальное право» / О. Г. Селихова. - Екатеринбург, 2002. -23 c., c. $13-14$

${ }^{16}$ Беседкина Н. И. Конституционно-правовая защита прав неродившегося ребенка в Российской Федерации : автореферат дис. На соискание науч. степени канд. юрид. наук : спец. 12.00.02 «Конституционное право; муниципальное право» / Н. И. Беседкина. - М., 2005. - 23 с., с. 12
} 
Supporting this approach, Professor A. I. Kovler emphasizes: "Modern law strongly defines another milestone: human life begins from the fertilization of the egg",

Unfortunately, at the legislative level, the moment of the beginning of life is not clearly established. And only in clause 1.2 of the Guidelines for determining the criteria of the perinatal period, live birth and dead birth, approved by the Order of the Ministry of Health № 179 on March 29,2006 , states that "live birth is the expulsion or removal of the fetus from the mother's body, which after expulsion/removal (regardless of the duration of pregnancy, whether the navel cord is cut and whether the placenta is detached) breathes or has any other signs of life, such as palpitation, cord pulsation, certain movements of skeletal muscles", ${ }^{18}$ although from this definition it is not clear what should be recognized as the beginning of life. The Instruction focuses on the criteria that indicate whether a person was born alive.

The decision on the problem of legal consolidation in relation to the moment when life protection begins should be found in terms of foreign, first of all, European legislative experience. In particular, under the legislation of most states of the European Union, human life begins at the time of his/her conception, and the child at the prenatal stage of development up to his/her birth by the very fact of his/her existence, including the fact of staying in physical (biological) relations with his/her mother, has a certain legal status that gives him/her the right to protection.

Traditionally, the prenatal period is divided into three stages: the zygote stage (about two weeks), the embryo stage (from the second to the eighth week) and the fetus stage (from the ninth week up to the birth). At the same time, the terms "zygote", "embryo" and "fetus" are used exclusively to indicate the stages of the ontogenetic development of the human individual, but can not in any way be the basis for recognizing the lack of value of the child's life at the prenatal stage of development.

In accordance with the Decree of the Grand Chamber of the European Court of Justice (Court of Justice of the European Union) in

\footnotetext{
${ }^{17}$ Ковлер А. И. Антропология права : учеб. для вузов / А. И. Ковлер. - М. : НОРМА - ИНФРА-М, 2002. -480 c., с. 428

${ }^{18}$ Про затвердження Інструкції з визначення критеріїв перинатального періоду, живонародженості та мертвонародженості, Порядку реєстрації живонароджених і мертвонароджених [Електронний ресурс] : наказ Міністерства охорони здоров’я України № 179 від 29 березня 2006 р. - Режим доступу : http://zakon2.rada.gov.ua/laws/show/z0427-06.
} 
case № C-34/10 on October $18,2011^{19}$, dedicated to the interpretation of Article 6, paragraph 2, subparagraph (c) of Directive 98/44/EC of the European Parliament and of the Council "On the legal protection of biotechnological inventions" ${ }^{20}$ on July 6, 1998, a human egg from the moment of fertilization should be considered as a "human embryo" (subparagraph 1 of paragraph 53 and paragraph 35; herein - "in terms of content and for the purposes of subparagraph (c) of paragraph 2 of Article 6 of the Directive").

Being at the initial - prenatal - stage of human life and development does not give legal grounds to treat a person (and accordingly - his/her life) as an object that is not a human individual and has no right to life and is not subject to criminal legal protection. The right of such a child to life by its legal nature derives from the natural human right to life and should be recognized as the highest value by the state. Thus, the state is obliged to recognize the necessity for legal protection of the child's life and health at the prenatal stage of development and to establish legislative guarantees of the right to life of such child; his/her right to normal development and the criminal legal protection of his/her health from the moment of conception.

One should turn to the legal position of the European Court of Human Rights, which reflects not only the legal positions on the issues proposed, but also the value-based (axiological) grounds for the decisions taken on these issues. Thus, according to the legal position set out in $\S 82$ of the European Court of Human Rights judgment on 07.07.2004 in the case "Vo v. France" 21 and later in $\S 107$ of the European Court of Human Rights in the case of "Mehmet Şentürk and Bekir Şentürk v. Turkey" on

\footnotetext{
19 Arrêt de la Cour de justice (Grande chambre) de 18 octobre 2011 dans l’affaire № C-34/10 // $<$ http://curia.europa.eu/juris/document/document.jsf?text=\&docid=111402\&pageIndex=0\&doclang=FR\&mode $=1$ st\&dir $=\&$ occ $=$ first\&part=1\&cid=416805>. Judgment of the Court of Justice (Grand Chamber) of 18 October 2011, Case C-34/10 // <http://curia.europa.eu/juris/document/document.jsf?text= \&docid=111402\&pageIndex= $0 \&$ doclang $=\mathrm{EN} \&$ mode $=1$ st $\& \operatorname{dir}=\&$ occ $=$ first $\&$ part $=1 \& \mathrm{cid}=416805>$.

${ }^{20}$ Directive № 98/44/CE du Parlement européen et du Conseil du 6 juillet 1998 relative à la protection juridique des inventions biotechnologiques // Journal officiel des Communautés européennes. - 30.07.1998. № L 213. - P. 0013-0021. <http://eur-lex.europa.eu/legal-content/FR/TXT/HTML/?uri=CELEX: 31998L0044 \&from=EN>. Directive № 98/44/EC of the European Parliament and of the Council of 6 July 1998 on the legal protection of biotechnological inventions // Official Journal. - 30.07.1998. - № L 213. - P. 0013-0021. <http://eur-lex.europa.eu/legal-content/EN/TXT/?uri=CELEX:31998L0044>.

${ }_{21}$ Arrêt de la Cour Européenne des Droits de l'Homme du 08.07.2004 de l'affaire «Vo c. France» (Requête № 53924/00) // <http://hudoc.echr.coe.int/sites/eng/pages/search.aspx?i=001-66445> .
} 
09.04.2013 (final judgment on 07.09.2013) ${ }^{22}$, in the absence of European consensus on the scientific and legal determination of the moment of the beginning of human life, the state has the right to independently resolve this issue: "The question of the starting point of the right to life shall be attributed to the discretion of the states themselves".

At the same time, in the resolution of the European Court of Human Rights on 08.07.2004 in the case "Vo v. France" it was stated that it was inappropriate to carry out the unification of the legislative norms of various states on this issue ( $(82)$, moreover, the Court noted that "certain elements of the legal protection of the human embryo/fetus arise in the light of scientific progress and future results of scientific research in the field of genetic engineering, artificial insemination or experiments on embryos"'(\$ 84).

According to the Constitutional Court of Spain resolution № 53/1985 on $11.04 .1985^{23}$, unborn children (subparagraph (c) of paragraph 5 etc.) have the constitutionally guaranteed right to life (as an embodiment of the fundamental value) and for, the state has an obligation to guarantee life, including for an unborn child (Article 15 of the Spanish Constitution), although within certain limits, determined by the interests of protecting the rights to life and health protection of the mother (paragraphs 12, 4 and 7); it is recognized that human life is a process of development that begins with pregnancy and ends with death, it is a continuous representation of qualitative changes in the physical and psychic nature over time, reflecting this in the changes in the status of the human individual from the point of view of public and private law (subparagraph (a) of paragraph 5).

The Resolution of the Constitutional Court of FRG on 28.05.1993 ${ }^{24}$ also confirmed the necessity to extend the right to life to children at the prenatal stage of development: "The basic law requires from the state to protect human life. Human life includes the life of the unborn. And this right must also be protected by the state" (paragraph 145). The German lawmaker represented by the Federal Constitutional Court of Germany, in

\footnotetext{
${ }^{22}$ Arrêt de la Cour Européenne des Droits de l'Homme (Deuxième section) du 09.04.2013 (Définitif 09.07.2013) de l'affaire «Mehmet Şentürk et Bekir Şentürk c. Turquie» (Requête № 13423/09) // <http://hudoc.echr.coe.int/sites/eng/pages/search.aspx?i=001-118336>.

${ }_{23}$ Sentencia del Tribunal Constitucional de España № 53/1985 de 11 de abril de 1985 // <http://hj.tribunalconstitucional.es/HJ/pt-BR/Resolucion/Show/SENTENCIA/1985/53>.

${ }^{24}$ Decision of the Federal Constitutional Court, №№ 2 BvF 2/90, 2 BvF 4/92, and 2 BvF 5/92, May 28, 1993 // <http://www.bverfg.de/entscheidungen/fs19930528_2bvf000290en.html>.
} 
his/her judicial practice still leaves the unsolved question from what period of life begins the protection of constitutional human rights. However, this higher judicial authority is more inclined to the fact that "human life begins with the merger of the egg and sperm" 25.

Accordingly, the assertion that an unborn child is a person is not only a philosophical, moral or ethical belief or assumption, but is legally significant established fact recognized by international law, confirmed by the provisions of EU international law $^{26}$ and substantiated by a greater amount of scientific knowledge gained in the fields biology, embryology, genetics, physiology and other sciences.

In the legislation of most European Union states, the norms that guarantee the right to life, health care and other rights of the child at the prenatal stage of development are enshrined. A number of fundamental rights must be legally recognized in a child at the prenatal stage, including the right to life, safety and protection, proper care and nutrition, special criminal law protection against all forms of negligent conduct, violence, intentional and unintentional harsh treatment and other actions that could cause harm to child's development.

It is obvious that at present the levels and specific measures of legal protection of a born person and legal protection of a person at the prenatal period of development vary significantly in different states, but this does not mean that the state's duty to observe and protect human rights at the prenatal period is less important (or that there is no such duty of the state at all) and that a person at the prenatal period is deprived of any legal protection.

Attention is drawn to clause 10 of the Recommendation of the Parliamentary Assembly of the Council of Europe № 1046 on 24.09.1986 "On the use of human embryos and fetuses for diagnostic, medical, scientific, industrial and commercial purposes" ${ }^{27}$, which draws attention

\footnotetext{
25 Гиряева В. Н. Хеун В. Исследования эмбрионов и конституция: право эмбриона на жизнь и человеческое достоинство. Heun W. Embryonenforschung und verfassung: lebensrecht und menschenwuerde des embryos // Juristen zeitung. - Tuebingen, 2002. - № 11. - S. 517-524 / В. Н. Гиряева // Социальные и гуманитарные науки. Отечественная и зарубежная литература. - Серия 4 : Государство и право : реферативный журнал. - 2004. - № 2. - С. 126-129., с. 127

${ }^{26}$ Конвенция о правах ребёнка / Принята Резолюцией № 44/25 Генеральной Ассамблеи ООН от 20.11.1989 // <http://www.un.org/ru/documents/decl_conv/conventions/childcon.shtml>.

27 Recommandation de l'Assemblée Parlementaire du Conseil de l'Europe № 1046 (1986) du 24 septembre 1986 «Utilisation d'embryons et foetus humains à des fins diagnostiques, thérapeutiques, scientifiques, industrielles et commerciales» // <http://assembly.coe.int/nw/xml/XRef/Xref-XML2HTMLen.asp?fileid=15080\&lang=fr > < <ttp://assembly.coe.int/nw/xml/XRef/X2H-Xref-ViewPDF.asp?FileID=15080 \&lang $=\mathrm{fr}>$.
} 
to the fact that "human embryos and fetus must be considered in all circumstances with respect for human dignity".

Thus, the legal recognition of the child at any stage of intrauterine development as the subject of the right to life, the legal recognition of the rights of such child to life, health and development, as well as to criminal legal protection before his/her birth is expressed in a number of provisions of international legal acts, and is also confirmed by legally established guarantees in the legal systems of many foreign countries.

The right of the child to life and to receive protection from harm to his/her health and threat to his/her life at the prenatal stage of development is guaranteed, above all, by a number of international acts. Thus, according to the preamble of the Declaration of the Rights of the Child, "the child, by reason of his physical and mental immaturity, needs special safeguards and care, including appropriate legal protection, before as well as after birth" 28 .

It should be noted that the Declaration of the Rights of the Child specifies only two specific rights of the child that have arisen since his/her birth, namely: the right to a name and the right to a nationality (Principle 3 ), at the same time there are no indication of other rights of the child that arise only from the moment of his/her birth in this Declaration, and such restrictions on other children's rights do not follow from it. However, the parents of the child have the right to give him/her a name and before his/her birth. Thus, the considered Declaration confirms possession of the child of a number of fundamental natural rights at the prenatal stage of development.

Interpretation of Principle 9 of the Declaration of the Rights of the Child is that "the child shall be protected from all forms of negligent attitude, cruelty and exploitation. He/she shall not be the subject of trade in any form whatsoever," and the provisions of its Preamble on ensuring the appropriate legal protection of the child, before as well as after birth, in their relationship, reveals their legal content, according to which the right of the child and, before his/her birth to be protected from all forms of negligent attitude, cruelty and exploitation and the need for States to provide such protection is recognized.

\footnotetext{
28 Декларация прав ребёнка / Принята Резолюцией № 1386 (XIV) Генеральной Ассамблеи ООН от 20.11.1959 // <http://www.un.org/ru/documents/decl_conv/declarations/childdec.shtml>.
} 
The preamble to the Convention on the Rights of the Child on 20.11.1989 $9^{29}$ states that its adoption was carried out, taking into account the above-mentioned imperative of the preamble of the Declaration of the Rights of the Child on 20.11.1959 on the need for legal protection and safeguard of the child before his/her birth as well. At the same time, in the same way as the Declaration of the Rights of the Child, the Convention on the Rights of the Child contains a clearly defined restriction on the beginning of the child's possession of rights and the beginning of their effect at the moment of his/her birth as the moment of beginning of the possession of the right - only concerning the right of the child to a name and the right of the child to a nationality, as well as the right to know their parents and their care (Article 7, clause 1). There are no other restrictions on the rights of the child in the part relating to the beginning of their occurrence and the beginning of their effect before the moment of the child's birth in the Convention on the Rights of the Child, indicating only the upper age limit of recognition of a person as a child (Article 1). And it is in the light of this provision of the Preamble that one should interpret Article 6, clause 1, of the said Convention on the duty of States Parties to recognize that "every child has the inherent right to life", reasonably extending the concept of "every child" to the child before his/her birth as well.

We consider as essential that, in accordance with Article 6, clause 2, of the Convention on the Rights of the Child, Member States to the maximum extent as possible ensure "the survival of the child". Consideration of this norm in conjunction with the provisions of the preamble of this Convention on ensuring the appropriate legal protection of the child, before as well as after birth, allows revealing its legal content, according to which the states are obliged to ensure the child's survival before as well as after his/her birth. Thus, this element of the child's legal status at the prenatal stage of development, namely, the state's obligation to ensure the survival of the child, is included to the composition guarantees of the right of such child to life.

Thus, the above international acts on the rights of the child (basic international acts on the rights of the child, most legally significant in the general scope of international human rights acts) guarantee the rights of the child to life, health protection and development, which is

${ }^{29}$ Конвенция о правах ребёнка / Принята Резолюцией № 44/25 Генеральной Ассамблеи ООН от 20.11.1989 // <http://www.un.org/ru/documents/decl_conv/conventions/childcon.shtml>. 
fundamentally important before the child's birth as well. At the same time, the minimum (lower) time (age) limit - the moment when the child's right to life, health protection and human dignity has appeared and become effective - has not been established in the international documents mentioned.

It should be noted that in the International Covenant on Civil and Political Rights on 16.12.1966 ${ }^{30}$, Article 6, clause 1 of which enshrined the inherent right of every person to life, the very moment of the occurrence and coming into force of the human right to life has not been indicated. The same is in the European Convention for the Protection of Human Rights and Fundamental Freedoms on $04.11 .1950^{31}$, in the provisions guaranteeing the right to life (Article 2, clause 1), there is no indication of the moment from which the emergence of the right to life in a person is recognized.

These and other international legal acts do not contain provisions based on which one could interpret legitimately convincing the human right to life in such a way that the moment of the emergence of this human right should be recognized not earlier than from the moment of person's birth. Thus, in accordance with Article 1, clause 6, of the European Convention on the Exercise of Children's Rights on $25.01 .1996^{32}$, nothing prevents the parties from applying more favorable provisions for the support and exercise of children's rights. Provided that according to the established common understanding of human life, it begins with conception, and the human birth is only a stage of life, and the necessity to provide safeguard and legal protection of human life essentially includes the child at the prenatal stage of development, we believe, that states have the right to take measures of the legal protection and safeguard of such child that are more intensive than it is guaranteed at the international level.

In addition, there are numerous examples of international human rights treaties that directly consolidate or express the recognition of the emergence of the human right to life and the beginning of the protection of this right from the moment of conception. Thus, in accordance with

\footnotetext{
30 Международный пакт о гражданских и политических правах / Принят Резолюцией № 2200 A (XXI) Генеральной Ассамблеи ООН от 16.12.1966 // <http://www.un.org/ru/documents/ decl_conv/conventions/pactpol.shtml>.

${ }^{31}$ Конвенция о защите прав человека и основных свобод, измененная и дополненная Протоколом № $11 / /<\mathrm{http}: / /$ conventions.coe.int/treaty/rus/treaties/html/005.htm>.

32 Европейская конвенция об осуществлении прав детей от 25.01 .1996 // <http://conventions.coe.int/Treaty/rus/Treaties/Html/160.htm>.
} 
Article 18 of the "Research on Embryos in vitro" of The Convention for the Protection of Human Rights and Dignity of the Human Being with regard to the Application of Biology and Medicine - the Convention on Human Rights and Biomedicine on 04.04.1997"33 "If conducting research on embryos In vitro permitted by law, the law shall ensure adequate protection of the embryo. Creation of human embryos for research purposes is prohibited".

In a number of documents of international organizations (documents of the so-called "soft" international law), such an approach is doctrinally supported and its value grounds are set forth. Thus, Articles 1-4 of the Declaration on 25.03.2011, "The Articles of San José"34 state that the beginning of a new human life at the moment of conception is the scientifically established fact as well as that "every human life is an inseparable whole that begins at the moment of conception and passes various stages to death."

In science, these stages are given different names, such as "zygote", "blastocyte", "embryo", "fetus", "infant", "child", "adolescent", and "adult". It does not change scientific consensus, according to which each individual is a living representative of the human race at every moment of his development. Every unborn child is a person by nature from the moment of his conception. All human beings, as representatives of the human race, have the right to recognize their inherent dignity and to protect their inalienable rights. This is recognized in the Universal Declaration of Human Rights, in the International Covenant on Civil and Political Rights and other international treaties".

Paragraph 5 of the Recommendation of the Parliamentary Assembly of the Council of Europe № 1046 (1986) on 24.09.1986, "On the use of human embryos and fetuses for diagnostic, medical, scientific, industrial and commercial purposes" 35 recognizes the objective fact that "from the fertilization of the egg, human life is developing continuously", so it is

\footnotetext{
${ }^{33}$ Convention pour la protection des Droits de l'Homme et de la dignité de l'être humain à l'égard des applications de la biologie et de la médecine: Convention sur les Droits de l'Homme et la biomédecine Oviedo, 4.IV.1997] // <http://conventions.coe.int/Treaty/fr/Treaties/html/164.htm>.

${ }^{34}$ Les Articles de San Jose // <http://www.sanjosearticles.com/?page_id=199\&lang=fr>; Статьи СанXoce // <http://www.sanjosearticles.com/?page_id=638\&lang=ru>.

35 Recommandation de l'Assemblée Parlementaire du Conseil de l’Europe № 1046 (1986) du 24 septembre 1986 «Utilisation d'embryons et foetus humains à des fins diagnostiques, thérapeutiques, scientifiques, industrielles et commerciales» // <http://assembly.coe.int/nw/xml/XRef/Xref-XML2HTMLen.asp?fileid=15080\&lang=fr $>;<$ http://assembly.coe.int/nw/xml/XRef/X2H-Xref-

ViewPDF.asp?FileID=15080\&lang=fr $>$.
} 
recognized that the beginning of human life should be considered from the moment of fertilization of the egg.

The necessity of protecting human rights and human dignity with respect to embryos, the necessity to respect the human dignity of human embryos, and the necessity for a certain legal protection of the human embryo from the moment of fertilization of the egg are discussed in clauses 1, 3 and 6 of the Recommendation of the Parliamentary Assembly of the Council of Europe № 1100 (1989) on 02.02.1989 "The Use of Human Embryos and Fetus in Scientific Research"36.

The constitutional guarantees of the protection of the rights and dignity of children at the prenatal stage of development are enshrined in a number of constitutions of the states in which they are reasonably included in the sections on human rights. In particular, Article II of the chapter "Freedom and Responsibility" of the Constitution of Hungary on 25.04.2011 ${ }^{37}$ states: "Human dignity is inviolable. Everyone has the right to life and human dignity, the life of the fetus is protected from the moment of conception". Clause $1 \S 3$ of the Hungarian Law on 23.12.2011 "On the Protection of Families" 38 establishes guarantees for the protection and respect of the child's life from the moment of conception. According to the preamble of the Hungarian Law on 17.12.1992 "On the Protection of the Life of the Human Fetus" (with subsequent amendments) ${ }^{39}$,"the life of the human fetus, starting from conception, deserves respect and protection." Pursuant to sub-clause (c), clause $3 \S 2$ of the Law of Hungary mentioned, the state ensures the protection of the human fetus.

Even if the positions (views) relative to the moment of the beginning of life differ among scholars, the necessity for legal (including criminal legal) protection of human embryos does not cause any objections. Thus, the Criminal Code of France contains the section on the human embryo protection, which includes Article 511-15. "The purchase of human embryos on payment terms in any form ..., the provision of mediation services to facilitate the purchase of human embryos on payment terms in

\footnotetext{
${ }^{36}$ Recommandation de l'Assemblée Parlementaire du Conseil de l'Europe № 1100 (1989) du 02.02.1989 «L'utilisation des embryons et foetus humains dans la recherche scientifique» // <http://assembly.coe.int/nw/xml/XRef/Xref-XML2HTML-fr.asp?fileid=15134\&lang=fr >.

${ }^{37}$ Magyarország Alaptörvénye // <http://www.njt.hu/cgi_bin/njt_doc.cgi?docid=140968>.

38 2011. Évi CCXI. Törvény a családok védelméről // <http://njt.hu/cgi_bin/njt_doc. cgi?docid=143096.245265>.

39 1992. Évi LXXIX. Törvény a magzati élet védelméröl // <http://njt.hu/cgi_bin/njt_doc. cgi?docid=17433.244667>.
} 
any form, or the paid transfer of human embryos to third parties", Article 511-16. "Receipt of human embryos without observance of the conditions provided by Articles L. 152-4 and L. 152-5 of the Code of Laws on Health", Article 511-17. "The implementation of conception in vitro (extracorporeal, i.e. carried out outside the maternal body, fertilization of the female egg, after which the embryo is transferred to the female's uterine cavity) of human embryos for industrial or commercial purposes". Use of human embryos for industrial or commercial purposes (Article 511-18). The code contains as well Article 511-19. "Studying an embryo or experimenting with it", Article 511-20. "Prenatal diagnosis without permission", Article 511-21. "Failure to comply with the provisions of Article L. 162-17 of the Code of Laws on Health related to pre-implantation diagnosis", Article 511-22. "Conduct of medical care activities without permission, Article 511-23. "The disclosure of personal information, which allows the couple to detect the couple, who abandoned embryo and the couple, who accepted it at the same time, Article 511-24. "Conduct of medical care activities for purposes other than those specified in Article L-152-2 of the Code of Laws on Health, Article 511-25. "Implementation of the embryo transplantation under the procedure established by Article L $152-5$ of the Code of Laws on Health, without clarifying the test results required for the implementation of the abovementioned article, for the detection of infectious diseases", etc.

\section{CONCLUSIONS}

The analysis conducted gives grounds to make a conclusion that the declarations of legal protection of the child at the prenatal stage of development are well-formulated in legislation of many countries of the EU. In their legislation many states have established the measures of the protection of child's right to life and health protection for children at the prenatal stage of development, including special measures for pregnant women's protection. Special criminal legal protection of the child at the prenatal stage of development is established, first of all, by consolidating the measures in criminal legislation aimed at increased protection of the life and health of the pregnant women from violent infringements.

Thus, the solution for the problem of legal consolidation of the moment in relation to the beginning of life protection should be found in the light of foreign, first of all, European legislative experience. In particular, under the legislation of most EU states, person's life begins at 
the moment of his conception, and the child at the prenatal stage of development before his birth has a certain legal status that gives him the right to protection by the very fact of his existence, including the fact of being in physical (biological) relations with his mother.

\section{SUMMARY}

The article deals with the important and controversial issues of determining the initial moment of person's life and his death in both law science and medicine. The reason for the problematic nature of this issue is the fact that both processes of birth and death are quite long, generating different points of view of scholars, both in the field of law and in the field of medicine. The works of national scientists involved in the development of this issue and the practice of the ECHR were analyzed. The theoretical provisions concerning the initial moment of human life were investigated and the value of the initial moment of human life for the criminal legislation was determined. As a result of the study, some proposals were made to improve Ukrainian legislation on the protection of human right to life.

Key words: initial moment, life, the right to life, crime, a person, birth, the end of life, death.

\section{REFERENCES}

1. Поппер К. Открытое общество и его враги: в 2 т. / К. Поппер. - Москва, 1992. - Т. 2. Время лжепророков: Гегель, Маркс и другие оракулы. - С. 76-77.

2. Schmitt C. Die Tyrannei der Werte / C. Schmitt. - Hamburg, 1979. - S. 33-37., c. 33.

3. Schmitt C. Die Tyrannei der Werte / C. Schmitt. - Hamburg, 1979. - S. 33-37., c. 34.

4. Isensee J. Burgerfreiheit und Burgertugend / J. Isensee // Der Preis der Freiheit. - Kцln, 1998. - S. 20.

5. Садовникова Г. Д. Комментарий к Конституции Российской Федерации (постатейный) / Г. Д. Садовникова ; отв. ред. Конюхова И. А. (Умнова). - Москва : Юрайт, 2000. - 189 с., с. 15-16.

6. Кант И. К вечному миру / И. Кант // Кант И. Соч. : в 6 т. Москва, 1966. - Т. 6. - С. 269-270. 
7. Мондін Б. Підручники систематичної філософії : в 6 т. / Б. Мондін ; пер. з італ. Б. Завідняка. - Жовква : Мicioнер, 2010. - Т. 3. Онтологія і метафізика. -284 с.

8. Позднышев С.В. Очерк основных начал науки уголовного права. Особенная часть М., 1923.

9. Набоков В.Д. Элементарный учебник особенной части русского уголовного права / В.Д. Набоков. - СПб : 1903. - 136 с.

10. Шарапов Р. Начало уголовно-правовой охрани жизни человека / Р. Шарапов // Уголовное право. - 2005. - № 1. - С. 70-81.

11. Трубников В.М. Концепція кримінально-правової охорони : монографія / В.М. Трубников, Т.А. Павленко. - Х. : Харків юридичний, 2009. - 288 с.

12. Глушков В. А. Ответственность за преступления в области здравоохранения / В. А. Глушков. - К. : Вища школа, 1987. - 200 с.

13. Коржанський М.Й. Кримінальне право. Законодавство України. Частина Особлива. Курс лекцій / М.Й. Коржанський. - К. : Атіка - 2001. - 544 c.

14. Попов А.Н. Преступления против личности при смягчающих обстоятельствах / А.Н. Попов. - СПб. : Юридический центр Пресс, 2001. $-472 \mathrm{c}$.

15. Порошук С.Д. Право людини на життя як об'єкт нормативноправового регулювання: сучасний стан, проблеми в Україні / С.Д. Порощук, О.В. Онуфрієнко // Вісник Луганського інституту внутрішніх справ МВС України: Наук.-теор. журнал. - Луганськ : Ін-т внутрішніх справ МВС України, 1998. - Вип. 2. - С. 3-18.

16. Голиченков В.А. Заявление кафедры эмбриологии биологического факультета МГУ 03.09.1993 [Электронный ресурс] / В.А. Голиченков, Д.В. Попов. - Режим доступа : http://www.patriarchia.ru/db/text/3122712.html.

17. Селихова О. Г. Конституционно-правовые проблемы осуществления права индивидов на свободу и личную неприкосновенность : автореферат дис. на соискание науч. степени канд. юрид. наук : спец. 12.00 .02 «Конституционное право; муниципальное право» / О. Г. Селихова. - Екатеринбург, 2002. - 23 с.

18. Беседкина Н. И. Конституционно-правовая защита прав неродившегося ребенка в Российской Федерации : автореферат дис. На соискание науч. степени канд. юрид. наук : спец. 12.00.02 
«Конституционное право; муниципальное право» / Н. И. Беседкина. - М., 2005. - 23 с.

19. Ковлер А. И. Антропология права : учеб. для вузов / А. И. Ковлер. - М. : НОРМА - ИНФРА-М, 2002. - 480 с.

20. Про затвердження Інструкції 3 визначення критеріїв перинатального періоду, живонародженості та мертвонародженості, Порядку реєстрації живонароджених i мертвонароджених [Електронний ресурс] : наказ Міністерства охорони здоров'я України № 179 від 29 березня 2006 р. - Режим доступу : http://zakon2.rada.gov.ua/laws/show/z0427-06.

21. Arrêt de la Cour de justice (Grande chambre) de 18 octobre 2011 dans 1'affaire № C-34/10 // <http://curia.europa.eu/juris/document/ document.jsf?text $=\&$ docid $=111402 \&$ pageIndex $=0 \&$ doclang $=$ FR \&mode $=1$ st\&dir $=\&$ occ $=$ first $\&$ part $=1 \&$ cid $=416805>$.

22. Judgment of the Court of Justice (Grand Chamber) of 18 October 2011, Case C-34/10 // <http://curia.europa.eu/juris/document/ document.jsf?text $=\&$ docid $=111402 \&$ pageIndex $=0 \&$ doclang $=\mathrm{EN} \&$ mode $=$ 1st\&dir $=\&$ occ $=$ first $\&$ part $=1 \&$ cid $=416805>$.

23. Directive № 98/44/CE du Parlement européen et du Conseil du 6 juillet 1998 relative à la protection juridique des inventions biotechnologiques // Journal officiel des Communautés européennes. 30.07.1998. - № L 213. - P. 0013-0021. <http://eur-lex.europa.eu/legalcontent/FR/TXT/HTML/?uri=CELEX:31998L0044\&from=EN>.

24. Directive № 98/44/EC of the European Parliament and of the Council of 6 July 1998 on the legal protection of biotechnological inventions // Official Journal. - 30.07.1998. - № L 213. - P. 0013-0021. $<$ http://eur-lex.europa.eu/legalcontent/EN/TXT/?uri=CELEX:31998L0044>.

25. Arrêt de la Cour Européenne des Droits de l'Homme du 08.07.2004 de l'affaire «Vo c. France» (Requête № 53924/00) // $<$ http://hudoc.echr.coe.int/sites/eng/pages/search.aspx?i=001-66445>.

26. Arrêt de la Cour Européenne des Droits de l'Homme (Deuxième section) du 09.04.2013 (Définitif - 09.07.2013) de l'affaire «Mehmet Şentürk et Bekir Şentürk c. Turquie» (Requête № 13423/09) // <http://hudoc.echr.coe.int/sites/eng/pages/search.aspx?i=001-118336>. 
27. Sentencia del Tribunal Constitucional de España № 53/1985 de 11 de abril de 1985 // <http://hj.tribunalconstitucional.es/HJ/pt-BR/ Resolucion/Show/SENTENCIA/1985/53>.

28. Decision of the Federal Constitutional Court, №o 2 BvF 2/90, 2 BvF 4/92, and 2 BvF 5/92, May 28, 1993 // <http://www.bverfg.de/ entscheidungen/fs19930528_2bvf000290en.html>.

29. Гиряева В. Н. Хеун В. Исследования эмбрионов и конституция: право эмбриона на жизнь и человеческое достоинство. Heun W. Embryonenforschung und verfassung: lebensrecht und menschenwuerde des embryos // Juristen zeitung. - Tuebingen, 2002. - № 11. - S. 517-524 / В. Н. Гиряева // Социальные и гуманитарные науки. Отечественная и зарубежная литература. - Серия 4 : Государство и право : реферативный журнал. - 2004. - № 2. - С. 126- 129.

30. Конвенция о правах ребёнка / Принята Резолюцией № 44/25 Генеральной Ассамблеи ООН от 20.11.1989 // <http://www.un.org/ru/ documents/decl_conv/conventions/childcon.shtml>.

31. Recommandation de l'Assemblée Parlementaire du Conseil de l’Europe № 1046 (1986) du 24 septembre 1986 «Utilisation d'embryons et foetus humains à des fins diagnostiques, thérapeutiques, scientifiques, industrielles et commerciales $\rangle / / \quad<\mathrm{http}: / /$ assembly.coe.int/nw/xml/ XRef/Xref-XML2HTML-en.asp?fileid=15080\&lang=fr >;

$<$ http://assembly.coe.int/nw/xml/XRef/X2H-Xref-

ViewPDF.asp?FileID $=15080 \&$ lang $=\mathrm{fr}>$.

32. Декларация прав ребёнка / Принята Резолюцией № 1386 (XIV) Генеральной Ассамблеи ООН от 20.11.1959 // <http://www.un.org/ru/ documents/decl_conv/declarations/childdec.shtml $>$.

33. Конвенция о правах ребёнка / Принята Резолюцией № 44/25 Генеральной Ассамблеи ООН от 20.11.1989 // <http://www.un.org/ru/ documents/decl_conv/conventions/childcon.shtml>.

34. Международный пакт о гражданских и политических правах / Принят Резолюцией № 2200 А (XXI) Генеральной Ассамблеи ООН от 16.12.1966 // <http://www.un.org/ru/ documents/decl_conv/ conventions/pactpol.shtml>.

35. Конвенция о защите прав человека и основных свобод, измененная и дополненная Протоколом № 11 // $<$ http://conventions.coe.int/treaty/rus/treaties/html/005.htm>. 
36. Европейская конвенция об осуществлении прав детей от 25.01.1996 // <http://conventions.coe.int/Treaty/rus/Treaties/Html/ 160.htm>.

37. Convention pour la protection des Droits de l'Homme et de la dignité de l'être humain à l'égard des applications de la biologie et de la médecine: Convention sur les Droits de l'Homme et la biomédecine Oviedo, 4.IV.1997] // <http://conventions.coe.int/Treaty/fr/ Treaties/html/164.htm>.

38. Les Articles de San Jose // <http://www.sanjosearticles.com/? page_id=199\&lang=fr $>$; Стать Сан-Хoce <http://www.sanjosearticles.com/?page_id=638\&lang=ru>.

39. Recommandation de l'Assemblée Parlementaire du Conseil de l'Europe № 1046 (1986) du 24 septembre 1986 «Utilisation d'embryons et foetus humains à des fins diagnostiques, thérapeutiques, scientifiques, industrielles et commerciales» // <http://assembly.coe.int/nw/xml/ XRef/Xref-XML2HTML-en.asp?fileid=15080\&lang=fr >;

$<$ http://assembly.coe.int/nw/xml/XRef/X2H-Xref-

ViewPDF.asp?FileID=15080\&lang=fr $>$.

40. Recommandation de l'Assemblée Parlementaire du Conseil de l’Europe № 1100 (1989) du 02.02.1989 «L'utilisation des embryons et foetus humains dans la recherche scientifique» // <http://assembly.coe.int/nw/xml/XRef/Xref-XML2HTMLfr.asp?fileid $=15134 \&$ lang $=\mathrm{fr}>$.

41. Allgemeines Bürgerliches Gesetzbuch (ABGB) // $<$ http://www.jusline.at/Allgemeines_Buergerliches_Gesetzbuch_(ABGB). html>.

42. Recommandation de l'Assemblée Parlementaire du Conseil de l’Europe № 1100 (1989) du 02.02.1989 «L'utilisation des embryons et foetus humains dans la recherche scientifique»// <http://assembly.coe.int/ nw/xml/XRef/Xref-XML2HTML-fr.asp?fileid=15134\&lang=fr $>$.

43. Recommandation de l'Assemblée Parlementaire du Conseil de l’Europe № 934 (1982) du 26.01.1982 «Ingénierie génétique» // $<$ http://assembly.coe.int/nw/xml/XRef/Xref-XML2HTMLfr.asp?fileid=14968\&lang=fr $>$.

44. Recommandation de l'Assemblée Parlementaire du Conseil de l'Europe № 1160 (1991) du 28.06.1991 «Elaboration d'une convention de bioethique» [«Разработка Конвенции о биоэтике»] // 
<http://assembly.coe.int/nw/xml/XRef/Xref-XML2HTMLfr.asp?fileid $=15194 \&$ lang $=\mathrm{fr}>$.

45. Уголовный кодекс ФРГ (1871 г.) по сот. на 17.08.1999 г. /пер. с нем. Под ред. А.В. Серебрянниковой. М., 2000. С.127-131.

46. Constitution of Ireland // <http://www.taoiseach.gov.ie/eng/ Publications/Publications_Archive/Publications_2012/Bunreacht_na_h\% C3\%89ireann-March2012.pdf >.

47. Anteproyecto de Ley Orgánica de protección de la vida del concebido y derechos de la mujer embarazada // <http://www.mjusticia.gob.es/cs/Satellite/1292426890214?blobheader=ap plication\%2Fpdf\&blobheadername1=Content -

Disposition\&blobheadervalue $1=$ attachment\%3B+filename\%3DAPLO_A BORTO_23-12-13_WEB.PDF.PDF>.

48. Arrêt de la Cour Européenne des Droits de l'Homme du 26.05.2011 (Définitif - 28.11.2011) de l'affaire «R.R. c. Pologne» (Requête № 27617/04) // <http://hudoc.echr.coe.int/sites/ fra/pages/search.aspx?i=001-104912>.

49. Sentencia del Tribunal Constitucional de España № 53/1985 de 11 de abril de 1985 // <http://hj.tribunalconstitucional.es/HJ/ptBR/Resolucion/Show/SENTENCIA/1985/53>.

50. Decision of the Federal Constitutional Court, №№ 2 BvF 2/90, 2 BvF 4/92, and 2 BvF 5/92, May 28, 1993 // http://www.bverfg.de/ entscheidungen/ fs19930528_2bvf000290en.html.

\section{Information about the author:} Dorokhina Yu. A.

Doctor in Law, Assistant Professor, Professor at the Department of Special Legal Disciplines of the Educational-Scientific Humanitarian Institute of the V. I. Vernadsky Taurida National University 